\title{
KÖMÜR YANMA ATIKLARININ ÇEVRESEL ETKILERİ VE KULLANIM ALANLARI
}

\author{
Gamze SÖNMEZ ${ }^{1, *(D), ~ M u s t a f a ~ I S ̧ I K ~}{ }^{2}$ \\ ${ }^{1,2}$ Aksaray Üniversitesi, Mühendislik Fakültesi, Çevre Mühendisliği Bölümü, 68100, Aksaray Türkiye
}

\begin{abstract}
ÖZET
Dünya genelinde kömür, petrol ve doğal gaz gibi enerji kaynakları yaygın olarak kullanılmakta ve bu kullanım sonucu ortaya çıkan atıklar önemli derecede ekonomik ve çevresel problemler meydana getirmektedir. Ülkemizde özellikle kömür kullanımına bağlı olarak ortaya çıkan atık miktarı oldukça fazladır. Oluşan atıklar genellikle kömürün yakıldığ1 termik santrallerden su ile taşınarak kül depolama sahalarında depolanmaktadır. Su ile temas sonrası atık barajlarından sızma veya atık barajının patlaması ile kömür külünün içerdiği toksik metaller çevre ortamında yayılabilmektedir. Yapılan birçok çalışmada kömür külü depolama alanın yanında yaşamanın kanser ve diğer hastalık risklerini artırdığını göstermiştir. Bu çalışmada kömür yanma ürünleri olarak tanımlanan bu atıkların genel özellikleri, bertaraf yöntemleri, geri kazanımları, endüstriyel faaliyetlerde kullanılabilme olasılıkları ve bu konudaki mevzuatla ilgili yapılmış çalışmalar değerlendirilmiştir. Sonuç olarak, mevcut sulu taşıma ve depolama yöntemi ile bertaraf edilen atık küllerin çevre ve insan sağlığı için risk taşıdığı, biran önce bu yöntemden vazgeçilerek atık küllerin değerlendirme alternatiflerin hayata geçirilmesi ve kuru depolama yöntemlerinin uygulanmasının teşvik edilmesi gerekliliğine işaret edilmiştir.
\end{abstract}

Anahtar kelimeler: Kömür yanma atıkları, Uçucu kül, Çevre kirliliği

\section{ENVIRONMENTAL EFFECTS OF COAL COMBUSTION WASTES AND USAGE AREAS}

\begin{abstract}
Energy sources such as coal, oil and natural gas are widely used around the world and the wastes resulting from this use cause significant economic and environmental problems. In our country, the amount of waste due to coal use is quite high. The wastes generated are usually transported by water from thermal power plants where coal is burned and stored in ash storage areas. After contact with water, leakage from waste dams or explosion of waste dam, toxic metals contained in coal ash can be spread in the environment. Many studies have shown that living next to the coal ash storage area increases the risk of cancer and other diseases. In this study we were evaluated that studies on the general properties of these wastes, which are defined as coal combustion products, the methods of disposal, their recovery, the possibilities to be used in industrial activities and legislation in this field. As a result, it has been pointed out that the waste ash disposed by the existing water transport and storage method carries a risk for the environment and human health, and that this method should be abandoned as soon as possible, and the implementation of the alternative alternatives of waste ashes and the application of dry storage methods should be encouraged.
\end{abstract}

Keywords: Coal combustion wastes, Fly ash, Environmental pollution

\section{GíRiș}

Enerji günümüzde tüm dünyada ve ülkenizde en çok konuşulan ve tartışılan konulardan birisidir. Dünya nüfusunun artış1, teknolojik gelişmeler ve insanların yaşam standartlarının artmasına bağlı olarak kişi başına düşen enerji tüketimi de her geçen gün artmaktadır. Dünyada kullanılan enerji kaynakları içerisinde en önemli paya sahip olan enerji kaynaklarından birisi de fosil yakıtlardır. Küresel olarak, kömürün enerji piyasası içerisindeki payı azalmasına rağmen toplam kömür tüketiminin 2040 yılına kadar \% 15 artması beklenmektedir [1]. Şu anda dünyadaki en büyük enerji kaynağı olan kömür, farklı ülkelerde elektrik üretiminde yaygın olarak kullanılmaktadır. Ülkemizde ise enerji ihtiyacını karşılamak üzere kurulan büyük kapasiteli kömür yakan termik santrallerde, düşük kalorili, kül oranı yüksek linyitler kullanılmaktadır [2]. 
Kömürün çeşitli amaçlarla ve özelliklede enerji üretimi amacıyla kullanımı sonucu farklı özelliklerdeki kömür yakma kalıntıları ortaya çıkmaktadır. Kömür küllerinden oluşan kömür yanma atıklarının üretimi ve depolanması, Amerika Birleşik Devletlerinde artan çevresel bir sorun ve halk sağlığı sorunudur. Amerikan Kömür Külleri Birliği'ne (ACAA) göre, 2014 yılında kömürle çalışan tesisler yaklaşık 130 milyon ton kömür yanma atığı üretmiştir $[3,4]$.

Kömür talebinin, özellikle Çin ve Hindistan'daki enerji üretim endüstrilerinin etkisiyle önümüzdeki on yıl için gelişmekte olan ekonomilerde büyümeye devam etmesi beklenmektedir [5]. Bu nedenle, kömür yanma ürünlerinin üretimi kaçınılmaz olarak artacaktır. 2010 yılında dünyadaki kömür yanma ürünlerinin toplam üretimi Şekil 1'de gösterildiği gibi yaklaşık 780 milyon ton olmuştur. Bu ürünün sadece yaklaşık \% 53,5 kullanılmış, geri kalanı ise depolama veya bertaraf alanlarına gönderilmiştir [6].

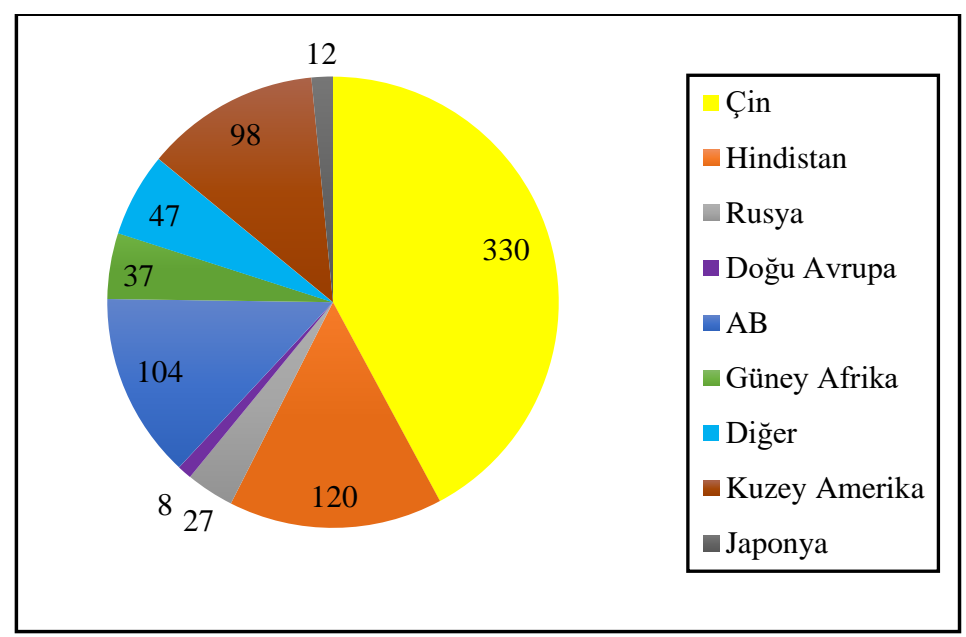

Şekil 1. 2010 yılında dünya çapında kömür yanma külü üretimi [6]

Ülkemizde ise kısa ve uzun vadeli enerji üretim stratejilerinin başında Termik Santrallerden üretilen enerji gelmektedir. Türkiye İstatistik Kurumunun yaptığı çalışmaya göre, Türkiye'de termik santrallerde 2003 yılında 11,84 milyon ton, 2004 y1lında 13,34 milyon ton, 2006 yılında 16,01 milyon ton ve 2008 yılında 19,66 milyon ton uçucu kül açığa çıkmıştır. 2020 yılına kadar yıllık uçucu kül miktarının ise 50 milyon tonu geçmesi beklenmektedir [7].

Dünyada ve ülkemizde kömür kullanımından oluşan atıklar daha çokta kömürün yakıldığı tesislerden uzaklaştırılmasına yardımcı olması için su ile taşınarak kül depolama sahalarında çamur olarak depolanmaktadır. Daha az uygulanmasına rağmen diğer bir uygulama ise kömürün yakıldığı termik santrallerin yakınında kuru olarak düzenli depolanmaktadır. Kömür külünün tarımsal ve mühendislik uygulamalarında geri kazanımı da söz konusu olabilmekte ve bazen de terk edilmiş maden ocaklarının doldurulmasında da kullanılmaktadır.

Bir santralde üretilen kömür yanma ürününü tipi, yakılan kömürün türü ve kazanın tasarımı ile belirlenir. Kömürün cevherine bağlı olarak kömür külü arsenik, kurşun, civa, kadmiyum, krom, selenyum gibi tipik olarak ağır metallerle birlikte alüminyum, antimon, baryum, bor, klorür, kobalt, manganez, molibden, nikel, talyum, vanadyum ve çinko gibi elementleri içermektedir [8]. Her tür kömür külünün özellikleri sadece kömürün türüne ve kaynağına ve kalitesine değil, aynı zamanda kömür madenciliği ve hazırlama yöntemine, yanma işlemine ve kullanılan emisyon kontrol teknolojisine de bağlıdır. Kömür yakma ürünlerinin kullanımından kaynaklanan çevresel ve insan sağlı̆̆1 etkileri, özellikleri ile ilgilidir [6].

$\mathrm{Bu}$ çalışmada kömür yanma atıkları ve özelliklede bu atıkların fiziksel ve kimyasal özellikleri üzerinde yapılmış çalışmalar değerlendirilmiştir. Çeşitli endüstriyel faaliyetlerde kullanılan veya farklı depolama yöntemleri ile yeraltı suyuna sızan ve havada kaçak toz emisyonu olarak bulunan kömür yanma ürünlerinin insan ve çevre sağlığı üzerindeki etkileri, bertaraf yöntemleri ve bu konudaki alternatifler üzerinde yapılmış çalışmalar tartışılmış ve günümüze kadar bu konuda yapılmış uygulamalar değerlendirilmiştir. Ayrıca kömür yanma atıklarının ülkemizde ve dünyada tabi olduğu mevzuat hakkında bilgi verilmiştir Sonuç olarak, çalışmanın atık yönetimi ve geri kazanımında ileri ülkelerde olduğu gibi ülkemizde de bu tür atıkların geri dönüşümü konusundaki alternatiflerin değerlendirilmesi ve bu tür uygulamaların yaygınlaşmasında olumlu katkılar sağlaması amaçlanmıştır. 


\section{KÖMÜR KÜLÜ VE FIZIIKSEL-KIMMYASAL ÖZELLIKLERİ}

Kömür, karbon ve çeşitli minerallerin (şeyller, killer, sülfitler ve karbonatlar) karışımından oluşan bir enerji kaynağıdır. Fosil kaynaklı bir mineral madde olan kömür, dört ana tipten biri olabilir [9].

-antrasit (>\% 90 karbon)

•bitümlü veya sert kömür (\% 80 karbon)

•linyit ve kahverengi kömür (<\% 70 karbon).

Kömür külü ise, kömür yakıldıktan sonra kalan atıktır. Uçucu külün yanı sıra firının dibine düşen iri malzemeleri içerir. Termik santrallerde, elektrik üretimi sırasında toz haldeki kömürün yanması sonucu baca gazları ile sürüklenen ve elektro filtreler yardımı ile tutularak atmosfere çıkışı önlenen mikron boyutunda kül tanecikleri meydana gelmektedir. Endüstriyel bir atık olan ve uçabilen bu küllere, uçucu kül (FA) adı verilmektedir. Bu işlem esnasında daha iri taneli olan ve baca gazları ile birlikte atmosfere sürüklenemeyerek kazan tabanına düşen küllere de taban külü (BA) denilmektedir [10].

Çoğu kömür külü kömürle çalışan elektrik santrallerinden gelir. Tüm dünyada enerji üretimi için yakılan kömürün tehlikeli bir yan ürünü olan milyonlarca ton kömür külü yüzey atık havuzlarında, barajlarda ve terk edilmiş madenlerde depolanmaktadır [11].

Üretilen kül tipi, kömürün mineral bileşenlerine ve kullanılan yanma tekniğine bağlı olarak farklılık gösterir. Kömür yakma yöntemleri ve emisyon kontrollerinden elde edilen fiziksel ve kimyasal formlara dayanarak; uçucu kül (FA), alt kül (BA), kazan cürufu (BS), baca gazı kükürt gidermeden (FGD) gelen ürünler olarak nitelendirilebilir. Uçucu küller kömür yakıtlı santrallerin bacalarında tutulurken, daha ağır alt kül ve kazan cürufu firının tabanından toplanır. FGD ürünleri ise, asit gazları ve bazı ağır metalleri gidermek için, bir alkali ajanın duman akışına püskürtüldüğü emisyon kontrol sistemleri ile üretilir [12]. Kül, cüruf ve uçucu kül oluşumunu gösteren tipik bir enerji tesisi akım şeması Şekil 2'de verilmiştir [13].

Bu kalıntılar içerisinde; uçucu kül, alt kül, kazan cürufu miktar olarak diğerlerinden çok daha fazla üretildikleri için Amerikan endüstrisi tarafından yüksek hacimli atıklar olarak adlandırılmaktadırlar [14]. Kömür yanma atıklarının genel özellikleri ve elde ediliş şekilleri Tablo 1'de özetlenmiştir.

Tablo 1. Kömür Yakma Atık Türleri [15]

\begin{tabular}{|c|c|c|}
\hline Attk Tipi & Özellikleri & $\begin{array}{c}\text { Toplam } \\
\text { üretimdeki } \\
\text { oranı }\end{array}$ \\
\hline Uçucu kül & $\begin{array}{l}\text { Elektrik üretmek için bir kazan içinde ince öğ̈̈̈tülmüş kömürün yanması } \\
\text { sonucu elde edilen üründür. Genellikle tesislerin bacalarında birikir veya } \\
\text { parçacıklı bir kontrol cihazı (örneğin, elektrostatik çökelticiler veya kumaş } \\
\text { filtreler) boyunca tutulur. Çoğunlukla silt ve kil boyutlu camsı kürelerden } \\
\text { oluşur. }\end{array}$ & $\% 57$ \\
\hline Baca Gazı & Baca gazı kükürt giderme (FGD), kükürt dioksit için geçerli olan Temiz & $\% 24$ \\
\hline $\begin{array}{l}\text { Kükürt Giderme } \\
\text { (FGD) }\end{array}$ & $\begin{array}{l}\text { Hava Yasasında emisyon gereksinimlerini karşlamak için uygulanan } \\
\text { kimyasal bir sürectir. İslemin amacı, kömür yakma isleminde acığa cıkan }\end{array}$ & \\
\hline Malzemesi & $\begin{array}{l}\text { kükürt gazlarını kimyasal olarak kireçtaşı (kalsiyum karbonat), kireç } \\
\text { (kalsiyum oksit) veya amonyak gibi bir sorbent ile reaksiyona sokmaktır. } \\
\text { Tesisde kullanılan kükürt giderme işlemine bağlı olarak, malzeme islak bir } \\
\text { çamur veya kuru bir toz olabilir. Islak çamur, muhtemelen baskın olarak } \\
\text { kalsiyum sülfit veya kalsiyum sülfattır. Kuru malzeme genellikle sülfitler ve } \\
\text { sülfatların bir karışımından oluşur. }\end{array}$ & \\
\hline Alt kül & $\begin{array}{l}\text { Baca gazları ile taşınamayacak kadar iri partiküllerdir. Fırın duvarlarına } \\
\text { çarparlar veya açı ızgaralardan firının tabanındaki kül hunisine düşerler. } \\
\text { Malzeme kazanın tabanından ya kuru formda ya da bir bulamaç olarak } \\
\text { alınır. Gözenekli bir yüzey yapısına sahiptir ve ince kumlardan ince } \\
\text { çakıllara kadar uzanan farklı tane boyutlarına sahiptirler. }\end{array}$ & $\% 17$ \\
\hline Kazan Cürufu & $\begin{array}{l}\text { Bu tür küller, suyla söndürülmü̈s olan bazı firınların tabanında toplanır. } \\
\text { Eriyik cüruf söndürme suyuyla temas ettiğinde, kırılır, kristalleşir ve } \\
\text { topaklar oluşturur. Bu cüruf malzemesi, düz, camsı bir görünüme sahip sert, } \\
\text { siyah, açısıl parçacıklardan oluşur. Parçacıklar, yüzey aşınmasına karşı bir } \\
\text { dirençli, boyut bakımından sert ve dayanıklıdır. }\end{array}$ & $<2$ \\
\hline
\end{tabular}




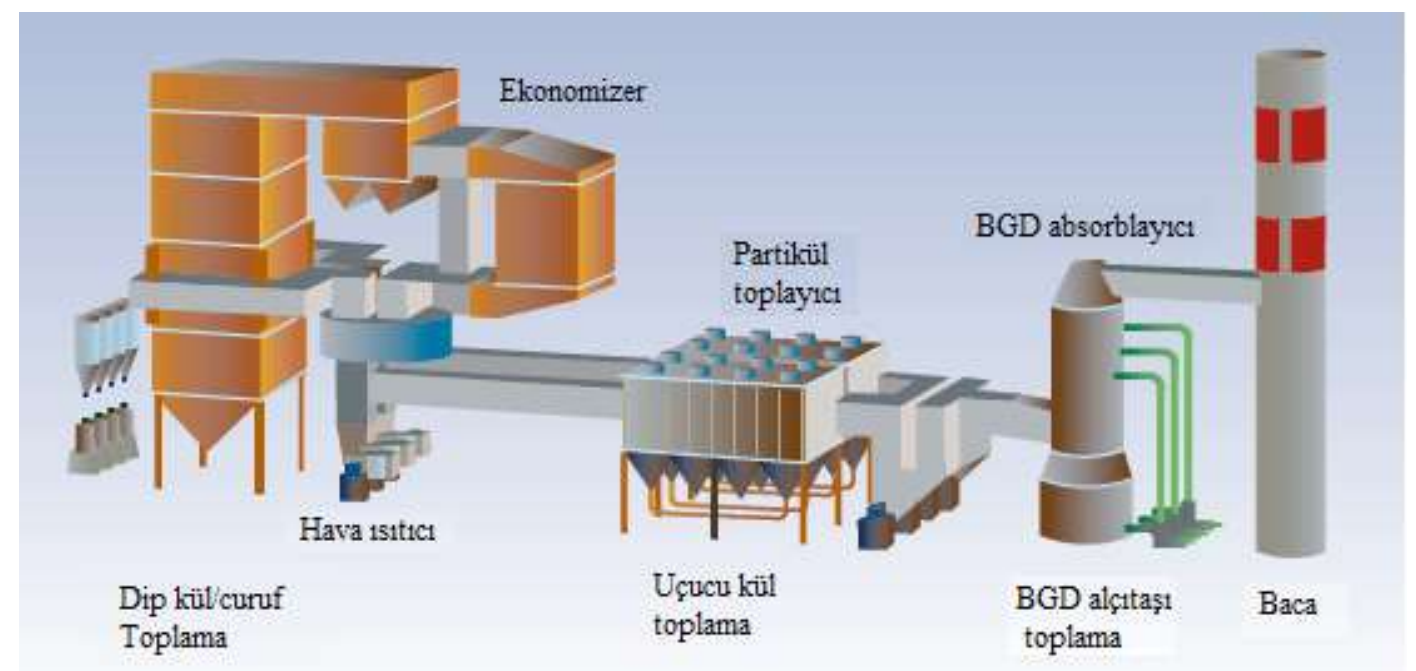

Şekil 2. Kül/cüruf ve uçucu kül oluşumunu gösteren tipik bir enerji tesisi akım şeması [13]

\subsection{Kömür Külünün Fiziksel Özellikleri}

Elektrik üretmek için yakılan kömür bu süreç sonunda \% 60'^ kömür külü olan ve kömür yanma atıkları olarak bilinen atık yan ürünleri oluşturur [16, 17]. Kömürün yüksek sıcaklıklarda yanması sonucunda ergimiş malzeme soğuyarak, kül taneciklerine dönüşmektedir. Bu kül tanecikleri çok ince olmaları nedeniyle baca gazları ile sürüklenir ve bu nedenle de uçucu kül olarak adlandırılırlar [18]. Uçucu küllerin renkleri açık krem renginden koyu kahverengiye kadar değişiklik gösterir. Renk yanmamış kömür oranından, demirce zengin danelerden ve nemden etkilenir [19, 20]. Uçucu kül partikülleri ince taneli, tipik olarak silt boyutlu, çapları 1 ila $100 \mu \mathrm{m}$ arasında değişen, ortalama partikül çapı 20 ila $25 \mu \mathrm{m}$ arasındadır [13]. Çoğu bitümlü kömür uçucu külünün parçacık boyutu dağılımı genellikle $75 \mu$ m'den azdır. Alt kül ve kazan cürufu uçucu küllerden daha iridir ve parçacıkların boyutu 0,1- 10 mm arasında değişebilir. Sıkıştırılmış ve kuru olduğunda, çoğu uçucu kül ve alt kül yapışkan toprağa çok benzer şekilde davranır [6, 14].

Kömür yakma külünün fiziksel özellikleri, parçacık büyüklüğü ve dağılımı, sıkıştırma davranışı, geçirgenlik ve kesme dayanımı ile ilgilidir. Tablo 2'de söz konusu fiziksel özelliklerin, uçucu kül ve alt külü/kazan cürufu için değerleri verilmektedir [13, 14]. Tablo 2'de verilen fiziksel özelliklerden; geçirgenlik(permeabilite), suyun belirli bir zaman diliminde atık malzemeden geçeceği hızı yansıtır. Sızmanın hızının ve miktarının belirlenmesinde önemlidir. Parçacıkların boyutu ve şekli, sıkıştırma derecesi ve suyun viskozitesi gibi bazı faktörler permeabilite derecesini etkileyebilir. Düzgün sıkılaştırılmış uçucu külün genellikle kilinkine benzer şekilde düşük geçirgenliği vardır, oysa alt külün geçirgenliği genellikle biraz daha yüksektir. Kazan cürufu geçirgenliği, çakıl taşlarınınkine benzer şekilde daha yüksektir. Kesme dayanımı, depolama sahalarında bertaraf edilen atıkların şekil ve yapısal stabilitesinin önemli bir belirleyicisidir [14].

Tablo 2. Uçucu kül, alt külü ve kazan cürufunun fiziksel özellikleri [13, 14]

\begin{tabular}{ccc}
\hline Özellikler & Uçucu Kül & Alt külü/Kazan cürufu \\
\hline Partikül boyutu $(\mu \mathrm{m})$ & $1-100$ & $100-10000$ \\
Sık1ştırılabilirlik $(\%)$ & 1,8 & 1,4 \\
Yoğunluk $\left(\mathrm{kg} / \mathrm{m}^{3}\right)$ & 1041 & 1762 \\
Nem içeriği $(\%)$ & $10-35$ & $12-26$ \\
Porozite $(\%)$ & $0,4-0,5$ & $0,25-0,4$ \\
Permeabilite $(\mathrm{cm} / \mathrm{s})$ & $10^{-6}-10^{-4}$ & $10^{-3}-10^{-1}$ \\
Birleşme $(\mathrm{Pa})$ & $0-1,17 \times 10^{6}$ & 0 \\
İç sürtünme açısı $\left({ }^{\circ}\right)$ & $25-45$ & $35-45$ \\
\hline
\end{tabular}

\subsection{Kömür Külünün Kimyasal Özellikleri}

Kömürün yanması sonucu oluşan kömür külünün yaklaşık \% 80'i, 1.98 ile $5.64 \mu \mathrm{m}$ arasında olan solunabilir aralıklı camsı kürelerden oluşan uçucu küldür $[17,21]$. Uçucu külde bulunan başlıca bileşenler $\mathrm{SiO}_{2}, \mathrm{Al}_{2} \mathrm{O}_{3}, \mathrm{Fe}_{2} \mathrm{O}_{3}$ ve $\mathrm{CaO}$ olup, bunların miktarları uçucu külün tipine göre değişmektedir. Ayrıca $\mathrm{MgO}, \mathrm{SO}_{3}$, alkali oksitler de minör bileşen olarak bulunmaktadır. Uçucu küldeki temel oksitlerden $\mathrm{SiO}_{2} \%$ 25-60, $\mathrm{Al}_{2} \mathrm{O}_{3} \% 10-30, \mathrm{Fe}_{2} \mathrm{O}_{3} \% 1-15$ ve $\mathrm{CaO}, \% 1-40$ oranlarında bulunmaktadır. 
Uçucu külün kimyasal bileşimi, kullanılan kömürün yapısı, jeolojik orijini ve proses koşullarına (kömür hazırlama, yanma, toz toplama, desülfirizasyon gibi) bağlıdır. Bu farklı aralıklardaki değerler uçucu külün tipini karakterize etmektedir [18]. Uçucu küllerde parçacık büyüklüğü azaldıkça ve yüzey alanı arttıkça, kömür külündeki kirletici konsantrasyonları artar. Bu nedenle de kömür külünün ana bileşeni olan uçucu kül, özellikle tehlikeli olma potansiyeline sahiptir [17, 21].

Uçucu kül partiküllerinden metallerin sızabilirliği, çevreleyen ortamın pH'sı ve uçucu kül partikül matrisindeki metallerin bulunabilirliğinden etkilenebilir [22]. Flues ve arkadaşları tarafından 2013'de yapılan çalışmada, uçucu kül partiküllerinde metallerin mevcudiyetinin toplam metal konsantrasyonundan farklı olduğunu bulmuştur. Çalışmada kadmiyum ve alüminyum da dahil olmak üzere metallerin çoğunluğu kömürde kömür külünden daha fazla kullanılabilirliğe sahip olmasının yanı sıra kömür külünün daha yüksek arsenik ve molibden mevcudiyeti tespit etmişlerdir. Kül parçacıklarında en çok bulunan metaller (\% 40'tan fazla) arsenik, kadmiyum ve molibdendir. Özellikle Arsenik'in kömür kül parçacıklarında kömürden daha yüksek bir mevcudiyete sahip olduğu bulunmuştur [22]. Kömür içerisindeki iz elementlerin yanma sırasında ve sonrasındaki davranışları Şekil 3'de gösterilmiştir.

Uçucu kül, doğal olarak kömürde bulunan yanmaz minerallerin erimesinden oluşur. Çok yüksek kömür yanma sıcaklıkları, kuvars, hematit gibi minerallerin bulunduğu mikroskobik cam partiküllerinin oluşmasına neden olur. Ayrıca kömür külünü içerdiği toksik maddeler çevrede erozyon, yüzeysel akışlar ve ince partiküller ve ya toz olarak hava yardımıyla taşınabilirler. Çevre Koruma Ajansı (EPA) tarafından resmi olarak kömür depolama alanlarının çevre ve insan sağlığı üzerindeki zararları olduğunu kanıtlanmıştır. EPA kömür külünün içme sularını, göletleri, dereleri ve nehirleri kirleterek zarar verdiği 70 vakayı tespit etmiştir [23].

Kömür külünün özellikleri, linyit, bitümlü kömür veya bitüm altı kömür gibi kaynak kömürün kendisinden ve işlenmedepolama için kullanılan tekniklerden de güçlü bir şekilde etkilenmektedir. Yanma süreçleri ve kazanın çalışma koşulları da bir etkiye sahiptir (Tablo 3). Külün kimyasal özelliklerini etkileyen faktörler tesis ve kömürün kaynağına bağlıdır ve arsenik, kadmiyum, krom, kobalt, kurşun, civa, selenyum, toryum ve uranyum gibi çeşitli toksik bileşiklerin yanı sıra dioksinler ve poli aromatik hidrokarbonlar (PAH) içerir.

Tablo 3. Uçucu kül ve alt külündeki elementlerin konsantrasyonları(mg/kg) [13]

\begin{tabular}{ccc}
\hline Elementler & Uçucu kül & Alt külü \\
\hline Alüminyum & $70,000-140,000$ & $59,000-130,000$ \\
Kalsiyum & $7,400-150,000$ & $5,700-150,000$ \\
Demir & $34,000-130,000$ & $40,000-160,000$ \\
Silisyum & $160,000-270,000$ & $160,000-280,000$ \\
Magnezyum & $3,900-23,00$ & $3,400-17,000$ \\
Potasyum & $6,200-21,000$ & $4,600-18,000$ \\
Sodyum & $1,700-17,000$ & $1,600-11,000$ \\
Kükürt & $1,900-34,000$ & TLA-15,000 \\
Titanyum & $4,300-9,000$ & $4,100-7,200$ \\
Antimon & TLA-16 & TLA \\
Arsenik & $22-260$ & $2,6-21$ \\
Baryum & $380-5100$ & $380-3600$ \\
Berilyum & $2,2-26$ & $0,21-14$ \\
Bor & $120-1000$ & TLA-335 \\
Kadmidyum & TLA-3,7 & TLA \\
Krom & $27-300$ & $51-1100$ \\
Bakır & $62-220$ & $39-120$ \\
Kurşun & $21-230$ & $8,1-53$ \\
Manganez & $91-700$ & $85-890$ \\
Civa & $0,01-0,51$ & TLA-0,07 \\
Molibden & $9,0-80$ & $3,8-27$ \\
Nikel & $47-230$ & $39-440$ \\
Selenyum & $1,8-18$ & TLA-4, \\
Stronsiyum & $270-3100$ & $270-2000$ \\
Talyum & TLA-45 & TLA \\
Uranyum & TLA-19 & TLA-250 \\
Vanadyum & TLA-360 & \\
Çinko & $63-680$ & \\
& TLA Tespit limitinin altında & \\
\hline & & \\
& &
\end{tabular}




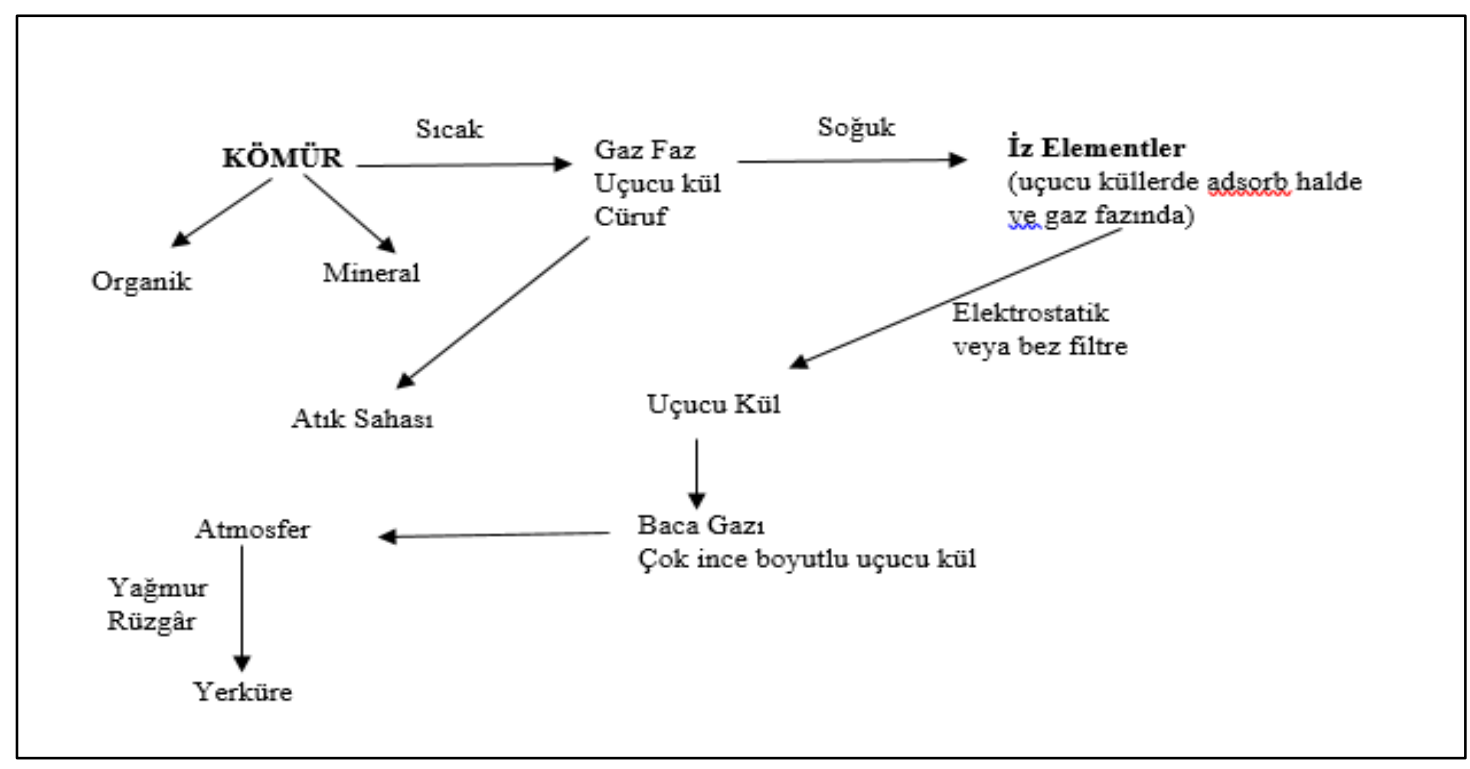

Şekil 3. Kömür içerisindeki eser elementlerin yanma sırasında ve sonrasında gösterdikleri davranışlar [2]

\section{KÖMÜR KÜLÜNÜN BERTARAF YÖNTEMLERİ VE KULLANIM ALANLARI}

\subsection{Bertaraf Yöntemleri}

Özellikle termik santrallerden çıkan sadece gaz emisyonları değil büyük miktarlardaki küller ve cüruf'da çevre kirliliği konusunda sorun yaratan atıklardır. Bu nedenle küllerin örtülerek bertaraf edilmesi yerine, değerlendirilmesi yönünde çalışmalar yapılmaktadır. Fakat kül miktarının fazla olması, söz konusu bu atıkların geniş alanlarda depolanmasını gerektirmektedir. Mevcut kömür külü depolama yöntemleri, çevredeki toplulukları yeraltı suyuna sızan veya havada kaçak toz emisyonu olarak kaçan kömür küllerine maruz bırakmaktadır [24]. EPA, 1,5 milyon çocuk da dahil olmak üzere 6 milyon insanın kömür külüne maruz kaldığını tahmin etmektedir [25].

Türkiye'de 2020 yılına kadar yıllık uçucu kül miktarının 50 milyon tonu geçmesi beklenmektedir [7].Bu nedenle bu tarz bir atığın ekolojik ve ekonomik olarak en uygun kömür külü bertaraf yöntemini seçmek çok önemlidir. En uygun yöntemin seçiminde topoğrafik, iklimsel, lojistik faktörler ve uyulması gereken mevzuat oldukça önemlidir[5].

Kömür külünün bertarafı için dört temel yöntem vardır.

- Kömür külünün sulu depolanması (Surface impoundment)

- Depolama (Landfill)

- Maden ocağı ve taş ocaklarına doldurma (mine and quarry fill)

- Okyanusta bertaraf (Ocean disposal)

Oluşan atıklar daha az sıklıkta kömürün yakıldığı termik santrallerin yakınında bulunan alanlarda kuru olarak düzenli depolanmakta, daha çokta kömürün yakıldığı tesislerden uzaklaştırılmasına yardımcı olması için su ile taşınarak kül depolama sahalarında çamur olarak depolanmaktadır. Kömür külünün yaklaşık yüzde 38'i, tarım ve mühendislik uygulamalarında bertaraf edilmek yerine "geri dönüştürülmektedir" ve ek olarak \%5'de terk edilmiş maden ocaklarına doldurulmaktadır [26].

EPA'ya göre, ABD'deki oluşan kömür külünün yaklaşık \% 70'i oluştukları sahada beratrafı yapılırken, yaklaşık üçte ikisi kömür külünün sulu depolanması şeklinde, diğerlerinin çoğu düzenli depolama şeklindedir. Okyanuslarda depolama henüz daha araştırma aşamasındadır. Madenlerde depolama yöntemi maden ocaklarının rehabilitasyonunda çöküntülerin önlenmesi açısından faydalı olabilir. Ancak günümüzde en yaygın yöntem kömür külünün sulu şekilde havuzlarda depolanması ya da kuru şekilde depolanması şeklindedir [6]. Dünyada ve ülkemizde kömür külünün sulu şekilde havuzlarda depolanması diğer yöntemler içerisinde en fazla tercih edilenedir.

Buna bağlı olarak bertaraf uygulamaları içerisinde iki durumda risk oldukça artırmaktadır. Bunlar kuru depolama yerine su ile taşıyarak depolanması ve depolama alanlarının sızdırmazlığının olmamasıdır. Yüzey barajları (1slak kül depolama havuzları) kuru düzenli depolama alanlarından daha yüksek riskler göstermektedir [27]. Kömür külü su ile temas ettiğinde, kömürün içerdiği toksik bileşenler suya geçebilir ve su ile taşınabilir. Bu nedenle de uçucu küllerin bünyesinde yer alan birçok eser element yüksek çözünürlükleri nedeniyle suya geçmekte ve potansiyel çevresel tehlikeler oluşturabilmektedir. Kömür külü depolama alanlarından kömür külü toksik maddelerini nehirlere, derelere ve göller gibi yüzeysel sulara ve insanların içme 
sularının sağladığı yeraltı su kaynaklarına sızdırdığg ve insanların yeni su kaynakları arayışına zorladığı 100 den fazla durum tespit edilmiştir. Hatta bir yerleşim yerinde kömür külü sızıntısın neden olduğu içme suyu kirlenmesi yüzünden ciddi bir yatırım da yapılmıştır [28].

\subsection{Kullanım Alanları}

Uçucu kül, çok çeşitli inşaat uygulamaları için uzun yıllardan beri kullanılmaktadır. Kullanımları betondaki çimentolu bir malzemeden basit bir dolgu malzemesine kadar çeşitlilik gösterir [9]. Söz konusu küllerin farklı kimyasal ve fiziksel yapıları nedeniyle söndürülmüş kireç ile birlikte su varlığında hidrolik bağlayıcılık özelliği kazandıkları için yapay puzolanlar sınıfında yer almaktadırlar. Bunun birlikte uçucu küllerin katkılı çimento, yüksek dayanımlı beton, portland çimentosu, hafif agrega, duvar elemanları üretiminde, geoteknik uygulamalarda ve yol yapımında kullanılmaktadır. Uçucu küllerin inşaat sektöründe kullanıldığı alanlar Tablo 4'de verilmektedir.

Tablo 4. Uçucu küllerin inşaat sektöründe kullanıldığı alanlar [10]

\begin{tabular}{cc}
\hline Malzeme & Kullanım amacı / yeri \\
Çimento Hammadde & Katkı ve ikame malzemesi \\
olarak \\
Beton & $\begin{array}{c}\text { İnce agrega, iri agrega ve hafif } \\
\text { agrega olarak } \\
\text { Katkı ve ikame malzemesi } \\
\text { olarak }\end{array}$ \\
Tuğla, ateş tuğlası & Katkı malzemesi olarak \\
Kerpiç & Bağlayıcı malzeme olarak \\
Yapı malzemeleri & Blok, panel, duvar, gaz beton, \\
& beton boru, cam, boya, seramik, \\
& plastik, harç Çeşitli yapılar / \\
& uygulamalar \\
Baraj, otoyol
\end{tabular}

Türkiye'de üretilen katkılı çimentolarda uzun yıllardır uçucu kül kullanılmaktadır. Çimento üretimi sırasında çok büyük miktarda doğal hammadde ve enerji tüketimi yapılmakta ve atmosfere $\mathrm{CO}_{2}$ gazı çıkmaktadır. Bu da sera etkisi yaparak iklim değişikliklerine neden olmaktadır. Bu yüzden çimento üretiminde uçucu kül kullanılması ile doğal çevrenin bozulması ve enerji tüketimi azalacağı gibi havadaki $\mathrm{CO}_{2}$ miktarı da azalacağı için küresel 1sınmanın en aza indirilmesi mümkün görülmektedir [10, 29].

Uçucu kül, düşük puzolanik reaktiviteye sahip bir kömür yanma yan ürünüdür [30]. Ancak, çimento veya klinkere katılacak puzolanların belirli bir özellikte olması gerekmektedir. Klinker ve beton uçucu küllerinin sahip olması gereken özellikler 'Türk Standartlarında" TS - 639 ve TS - 640'da verilmiştir [2].

Yapılan bir çalışmada uçucu külün tuğla yapımında kullanımı ile bir atık malzemenin doğaya verilerek çevre kirlenmesinin engellenmesi yanı sıra; külün ekonomik bir değer kazanması, değirmende öğütme kolaylığı sağlaması, kalıplama ve presleme için daha az güç gereksinimi, kolay kuruma gibi avantajlar elde edildiği belirtilmiştir [31]. Söz konusu çalışmada; kimyasal bileşimi, uygun radyoaktivite değerleri ve fiziksel özellikleri itibariyle inşaat sektörünün her alanında kullanım değerine sahip olan Çatalağzı termik santrali uçucu küllerinin \%30-40 oranında kullanımı ile uygun nitelikte tuğla üretilebildiği belirlenmiştir. Çalışmada ayrıca tuğlalarda meydana gelen kireç kusması kaynaklı beyazlaşmanın uçucu kül kullanımı ile ortadan kalktığının tespit edilmiştir [31].

Singh ve Siddique (2015) [32] ise yaptıkları bir çalışmada kömür taban külünün betonda nehir kumu yerine kullanılabilme olasılığını değerlendirmek için laboratuvar testleri yapılmıştır. Çalışma sonucunda betonun mukavemet ve dayanım özellikleri üzerinde önemli bir olumsuz etkisi olmadığı görülmüştür. Betondaki nehir kumu kütle bazında farklı oranlarda kömür külü gibi endüstriyel bir yan ürünle değiştirilerek, inşaat endüstrisi için teknik ve ekonomik açıdan faydalı sağlanabileceği belirtilmiştir. Böylelikle kömür taban külü kullanımının, doğal kaynakların sürdürülebilirliği konusunda büyük öneme sahip olduğu ortaya konulmuştur [32].

Uçucu küllerin inşaat sektöründe kullanımı ile ilgili yapılan başka bir çalışmada ise; Seyitömer Termik Santralinden uçucu kül örnekleri alınarak hafif yapı blokları üretimi amacı ile deneysel çalışmalar yürütülmüştür. Bu amaçla ana hammadde olarak uçucu kül ve bağlayıcı olarak kireç-alçı kullanılmıştır. Farklı oranlarda karışım yapılarak deney numuneleri üretilmiştir. Üretilen beton örnekleri üzerinde mekanik testler yürütülmüştür. Sonuç olarak Türkiye' deki uçucu küllerin hafif yap1 malzemesi üretiminde kullanılabileceği belirlenmiştir [33]. Uçucu küllerin inşaat sektöründe kullanımı özelliklede çimento üretimi için farklı türdeki küllerin kullanımı hem geri dönüşümü desteklediğini hem de atık depolama alanlarını asgariye 
indirmekte ve ayrıca da faydalı ikincil malzemeler üretmek konusunda önemli bir katkı sağladıklarından bu konuda dünya genelinde artan bir ilgi vardır.[34]

İnşaat sektörü dışında diğer sektörlerde de uçucu küllerin tekrar kullanımı konusunda yapılan farklı bir çalışmada ise; evsel atık sularda uçucu kül 'ün koagülant olarak etkinliği alüminyum sülfat ve demir klorür gibi koagülantlarla karşılaştırılarak incelenmiştir. Ülkemizdeki dört farklı termik santraldan temin edilen farklı kimyasal bileşimlere sahip uçucu kül örnekleri için yapılan çalışmada pıhtılaştırma-yumaklaştırma işlemlerinde etkin mekanizmanın, pH ve uçucu külün kimyasal bileşimine bağlı olarak değiştiği belirlenmiştir. Uçucu külün koagülant olarak etkinliği kalsiyum içeriğinin artmasıyla artmaktadır. En yüksek arıtma verimleri Yeniköy Termik Santralı'ndan çıkan uçucu kül kullanılarak elde edilmiştir [35].

Binici ve arkadaşları (2012) [36] yaptıkları çalışmalarında ise uçucu külü ısı ve ses yalıtımı sağlamak amacıyla üretilen sunta plaklarda katkı malzemesi olarak değerlendirmişlerdir. Bu amaçla Kahramanmaraş tekstil fabrikalarından elde edilen atık malzeme (pamuk atığı), Kahramanmaraş Afşin-Elbistan bölgesinde bulunan termik santrallerinin atığı olan uçucu kül ve yapıştırıcı reçine kullanılmıştır. Pamuk atığı ve uçucu kül ile desteklenmiş olan sunta plakaların mühendislik özelliklerinde pozitif yönde gelişme olduğu görülmüştür. Bu çalışma ile pamuk atığı, uçucu kül ve yapıştırıcı reçine kullanılarak üretilen hafif yapı malzemelerinin 1sı ve ses yalıtımı için kullanabileceği gösterilmiştir [36].

Güler ve arkadaşları (2005) [37] yaptıkları araştırmalarda; uçucu kül atıklarının bir taraftan yarattığı sorunlar ve bu sorunların enerji üretimine paralel olarak artışı, diğer taraftan endüstriyel artık olarak geri kazanılmaya elverişli bir malzeme niteliği taşıması, çeşitli alanlarda değerlendirilmesi olanaklarının araştırılmasına neden olduğunu belirtmişledir. Uçucu kül ve termik santralde onunla birlikte oluşan cürufun, içerdiği toksik maddelerin bir şekilde zararsız hale getirilmiş olması koşuluyla, mühendisliğin çeşitli dallarında, endüstride çeşitli metallerin eldesinde, hatta tarım alanına kadar çok geniş uygulama sahası bulunabileceği belirtilmiştir. Termik santral atıklarının bu şekilde değerlendirilmesi, depolama sorununu büyük ölçüde ortadan kaldıracağı gibi, çevresel sorunları bertaraf edecek, özellikle kısıtlı diğer doğal hammaddelerden tasarruf edilmesini sağlayacağı, bunların da ötesinde nitelik ve nicelik açısından daha iyi ürünler elde edileceği belirtilmiştir [37].

Uçucu kül çıktısının, dünya genelinde kömürle dayalı enerji üretimi devam ettiği sürece büyümeye devam edeceği tahmin edilmektedir. Bu konuda Çin, en büyük kömür tüketicisidir ve dünya çapındaki uçucu kül miktarının yarısından fazlasına katkıda bulunmaktadır. Çin Ulusal Kalkınma ve Reform Komisyonu istatistiklerine göre, yıllık uçucu üretimi 580 milyon tona ulaşmış ve bu oran artmaya devam etmektedir [30]. Tüm dünyada olduğu gibi ülkemizde' de bu tür atıkların kullanım alanının büyümesi ya da yeni kullanım alanlarının bulunması sonucu çevresel, toplumsal ve insan sağlığı üzerindeki etkileri azalacaktır. $\mathrm{Bu}$ konuda yapılan çalışmalar tüm dünyada ve ülkemizde artmış ancak uygulamaların genelleştirilmesi sağlanmamıştır. Özellikle uçucu kül kullanımının çevresel ve toplumsal açıdan sağlayacağı yararlar Tablo 5'de özetlenmiştir.

Tablo 5. Uçucu kül kullanımının çevresel ve toplumsal etkiler açısından sağlayacağı yararlar [20]

\begin{tabular}{|c|c|}
\hline Çevresel Yararlar & $\begin{array}{ll}\text { - } & \text { Doğal Çevrenin Korunumu } \\
\text { - } & \text { Çimento ve tuğla üretiminde daha az kil kullanılması } \\
\text { - } & \text { Uçucu külün kullanılması sonucu tarımsal alanlar, su } \\
& \text { kaynakları ve bitki örtüsü zarar görmeyecektir. } \\
\text { - } & \text { Stmosferik etkiler sonucu hava kirliliği olmayacaktır. } \\
\text { - } \quad \text { Çimento üretiminde daha az enerji kullanımına bağlı } \\
\text { - } \quad \text { Radarak atmosfere daha az } \mathrm{CO}_{2} \text { gazı karışacaktır } \\
\text { - } \quad \text { Sağlıklı besin zincirinin oluşması } \\
\text { - } \quad \text { Asit Yağmurlarının azalması } \\
\text { - } \quad \text { Dayanıklı yapı malzemeleri elde edilmesi } \\
\text { - Fiziksel, kimyasal ve mekanik özellikler açısından daha } \\
\quad \text { kaliteli, dayanıklı ve ekonomik yapı malzemeleri elde } \\
\text { - } \quad \text { Çevre dostu yapı malzemeleri elde edilmesi } \\
\text { - } \quad \text { Enerji tasarrufu ve ülke ekonomisine katkı }\end{array}$ \\
\hline Toplumsal Yararlar & $\begin{array}{l}\text { - } \quad \text { Bedensel etkilerde önemli ölçüde azalma } \\
\text { - } \quad \text { Zihinsel etkilerde önemli ölçüde azalma }\end{array}$ \\
\hline
\end{tabular}




\section{KÖMÜR KÜLÜNÜN BERTARAFI İLE İLGILİ MEVZUAT}

ABD EPA, kömür yanma atıklarının bertarafı konusunda büyük miktarda çalışma yürütmüştür. Diğer ülkelerde ise söz konusu atıkların yönetimi ile ilgili bilgiler yeterli değildir. Ayrıca bu konu ile ilgili mevzuat ülkeden ülkeye farklılık gösterebilmektedir. Geleneksel olarak, endüstriyel atıklar, katı atıklar veya tehlikeli atıklar olarak sınıflandırılmakta ve çoğu ülkede kömür külleri katı atık olarak kabul edilmektedir. Bu, kömürün kullanımını teşvik etmek ve kamu hizmeti sektörü üzerinde gereksiz bir düzenleyici yükten kaçınmak amacıyla ya da kömür külünün yeniden kullanımını mümkün kılmasını sağlaması için olabilir [6]

Kömür yanma atıkları toksik maddeler içermelerine rağmen, bu atıklar EPA tarafından tehlikeli atık olarak düzenlenmemiştir ve çoğu zaman kömürle çalışan güç santrallerinin yakınında ve bazı durumlarda yüksek su baskın riski olan bölgelerde büyük miktarlarda tutulmuştur [6].

Bugüne kadar, kömür külü atıklarını ele alan tek uluslararası anlaşma, Birleşmiş Milletler (BM) ve Ekonomik İşbirliği ve Kalkınma Teşkilatı Konseyi (OECD), tarafından imzaya açılan, tehlikeli atıkların uluslararası hareketlerinin kontrolü ve bertarafı hakkında ki Basel Sözleşmesidir. Sözleşme 1989 yılında imza için açılmış ve 5 Mayıs 1992'de yürürlüğe girmiştir. Mart 2013 itibariyle, 180 ülke ve Avrupa Birliği, Sözleşmeye taraf olurken, Haiti ve ABD Sözleşmeyi imzalamışlar ancak onaylamamışlardır.

Basel Sözleşmesi, atıkların tehlikeli olup olmadığını belirlemek için iki aşamalı bir süreç belirlemiştir. Buna göre kömür külleri, ya da sızıntıları Ek III özelliklerini sergilemelerine neden olan seviyelerde Ek I maddeleri içermedikçe tehlikeli bir atık değildir.

Basel Sözleşmesine ek olarak, The Council C (2001) 107/Final (OECD, 2004) OECD Kararı, geri kazanım ve yeniden kullanım operasyonları için atılan atıkların sınır ötesi taşınımı kontrolüyle ilgilidir. Bu doküman geri kazanım prosedürlerine tabi tutulabilecek atık kategorilerini belirler. Bu liste kömür yakıtlı enerji santrallerinden alınan uçucu kül, alt kül ve cürufu içerir ve geri kazanım koşullarını belirler. OECD tavsiyesi şu şekildedir: Atıkların tehlikeli özelliklerine göre sınıflandırılması yerel veya bölgesel koşullardan bağımsız olmalıdır [6].

Kaynak Koruma ve Kurtarma Yasası (RCRA), tüm atıkların yönetildiği genel yönergeleri sağlar. Ayrıca, kanunun uygulanması için kapsamlı bir yönetmelik seti geliştirmek üzere EPA'ya yönelik bir kongre görevini de içermektedir. 1976 yılında yürürlüğe giren RCRA, kısmen, insan sağlığını ve çevreyi, atık bertarafının olası tehlikelerinden korumak ve atıkların çevreye duyarlı bir şekilde yönetilmesini sağlamak amacıyla tasarlanmıştır. [15]. Genel olarak, endüstriyel atıklar "katı atık" ve "tehlikeli atıklar" için geçerli standartlara uygun olarak düzenlenmektedir. CCW yönetimiyle ilgili mevcut tartışma, CCW'nin bu kategorilerden hangisine ait olduğunu belirlemeye yöneliktir. Mevcut yönetmelikle ilgili zorlukların bir kısmını anlamak için, bir atığın katı bir atık veya tehlikeli bir atık olarak nasıl tanımlandığını (düzenleyici tanım uyarınca) ve EPA'nın her bir atık kategorisini düzenlemek için mevcut otoritesini anlamak yararlı olacaktır. RCRA düzenlemeleri, katı atıkları atılan herhangi bir malzeme olarak geniş bir şekilde tanımlamaktadır. Düzenlemeler, aşağıdaki özelliklerden birini veya birkaçını (toksisite, reaktivite, tutuşabilirlik veya aşındırıcılık) sergileyerek katı atıkların tehlikeli atık haline geldiğini belirtir. CCW tehlikeli olarak nitelendirilecekse, bunun nedeni atıklardaki tehlikeli bileşenlerin yasal toksisite seviyelerini aşması olabilir. EPA'ya göre toksisite özellikleri Toksisite Karakteristik Liç Prosedür (TCLP) kullanılarak tespit edilmesini gerektirir. TCLP testi, bir depolama sahasında oluşabilecek koşulları simüle etmeye yöneliktir ve toksik bileşenlerin yeraltı suyuna sızma potansiyelini ölçer. CCW'ler genellikle kurşun, arsenik, selenyum veya diğer ağır metaller gibi bazı kirleticiler için toksisite seviyelerini aşmaz. Bununla birlikte, CCW'nin doğası, diğer tehlikeli atıklara göre benzersizdir ve büyük hacimlerde üretilir [15].

\section{KÖMÜR KÜLÜNÜN ÇEVRE VE İNSAN SAĞLIĞINA ETKİLERİ}

Kömürün yanması sonucu ortaya çıkan atık maddelerin büyük miktarlara ulaşması ile ekonomik ve çevresel etkilerden dolayı büyük sorunlar ortaya çıkmaktadır. Kömür külleri kimyasal özellikleri nedeni ile uygun şekilde yönetilmediği ve uygun kontrol önlemleri alınmadığı zaman insan ve çevre sağlı̆̆ı üzerinde risk oluşturabilecek bazı tehlikeli bileşenleri içermektedir.

Kömür külü içerisindeki toksik maddelerin yenmesi, içilmesi veya solunması durumunda kanser, bilişsel bozukluklar, gelişimsel gecikmeler, davranış sorunları gibi sinir sistemi etkilerine ve ayrıca kalp hasarı, akciğer hastalığı, solunum sıkıntısı, böbrek hastalığı, üreme sorunları, gastrointestinal hastalık, doğum kusurları ve çocuklarda kemik büyümesinde bozulma gibi rahatsızlıklara neden olabilmektedir [8].

Çevre Koruma Ajansı (EPA), bir kömür külü atık sahasının yanında yaşamanın, kanser veya diğer hastalıklara yakalanma riskinizi artırabildiğini belirlemiştir. Bir sslak kül göleti (yüzey su tutma) yakınında yaşıyorsanız ve içme suyunuzu bir kuyudan alıyorsanız, arsenikle kirlenmiş suyu içmekten kansere yakalanma olasılığınız 1/50'ye yükselmektedir [27]. EPA tarafından yapılan bir risk değerlendirmesine göre, sslak kömür külü depolama havuzunun yakınında yaşamak, günde bir paket sigara içmekten daha fazla tehlikeli olduğu tespit edilmiştir [11]. Arsenik, kömür küllerinden kaynaklanan en yaygın ve en 
tehlikeli kirleticilerden biridir. EPA ayrıca kül havuzlarının yakınında yaşamanın kadmiyum, kurşun ve diğer toksik metallerden kaynaklanan hasar riskini artırdığını da bulmuştur [8].

Yapılan bir çalışmada çocukların uçucu küle maruz kalma riski yetişkinlere oranla daha yüksek ve kömür külünün sağlık etkilerine karşı daha hassas oldukları tespit edilmiştir. Bunun nedeni ise çocukların yetişkinlere oranla daha yüksek miktarda solunum yapmaları ve ortamdaki partikül maddelere maruz kalmayı artıran zemine yakın oynama eğiliminin fazla olmasıdır $[38,39]$.

Yapılan başka bir çalışmada ise; kömür külünün depolandığı alanların yakınlarında yaşayan çocuklarda sağlık ve uyku problemlerinin görülme sıklı̆̆ bu tarz bir etkiye maruz kalmayan çocuklarla karşılaştırılmıştır. Genel olarak 10,3 yaş ortalamasındaki çocuklarda 2013'den 2014'e kadar yapılan değerlendirmede Kentucky'deki bir santralin yakınında yaşayan ve kömür külüne maruz kalan çocuklarda astım, dikkat eksikliği hiperaktivite bozukluğu, gastrointestinal problemler, uykuya dalma zorluğu, sık gece uyanmaları, uyku konuşması ve bacak krampları şikâyeti daha fazla görülmüştür. Kurşun, civa ve arsenik gibi çeşitli kömür külü bileşenleri, çocuklardaki sağlık ve uyku problemleri ile ilişkili olabileceği düşünülmüştür [40].

2008 Noel'inden hemen önce Kingston/Tennessee de bir kömür yakıtlı enerji santralinin, 40 akrelik ( 16 hektar) bir kömür kül atık havuzunun toprak duvarı yıkılmıştır. Bir milyon galondan fazla su ve kömür külü, bitişik nehir vadisine dökülerek, 300 hektarlık bir alanın kalın ve toksik çamurla kaplanmasına, üç evin yıkılmasına ve Emory ve Clinch Nehirlerinin kirlenmesine neden olmuştur. EPA bu olaydan sonra civardaki su örneklerini test ettiğinde içme suyu standartlarının 149 katı arseniğe ve kurşun, talyum, kadmiyuım, krom, cıva ve nikel gibi metallerin değerlerinin yüksek olduğunu tespit etmiştir [41]. Bu dökülmenin ardından bölgede yapılan bir çalışma ile kömür külü toksik elementlerin yüksek derişimlerini ( $\mathrm{As}=75 \mathrm{mg} / \mathrm{kg}$, $\mathrm{Hg}=150 \mu \mathrm{g} / \mathrm{L})$ ve radyoaktivite $(226 \mathrm{Ra}+228 \mathrm{Ra}=8 \mathrm{pCi} / \mathrm{g})$ içerdiği ve bunların havaya tekrar ince partikül şeklinde $(<10 \mu \mathrm{m})$ yayılarak bölge insanı için potansiyel sağlık riski oluşturma riskinin olduğunu ifade edilmiştir. Ayrıca kömür külünün içerdiği toksik maddelerin sızarak sınırlı su yenilenme potansiyelinin olduğu yerlerde yüzeysel su kaynaklarının kirlenme potansiyelinin olduğunu belirtmişler, fakat bölgedeki Emory ve Clinch Nehirlerinde yapılan analizlerde nehirdeki seyrelmeden dolayı sadece bu kirleticilerin iz seviyelerini tespit etmişlerdir. Nehir sedimentlerinde tespit edilen civa ve arsenik açısından zengin kömür külünün nehirlerin mansap tarafında oluşacak anaerobik koşullarda metil civa oluşumu ve balık zehirlenmesine neden olabileceği de tespit edilmiştir [42].

\section{SONUÇLAR}

Sonuç olarak kömür çok önemli bir enerji kaynağı olarak ülkemizde ve tüm dünyada kullanıldığından böyle bir kaynağın kullanımı sonucu ortaya çıkacak atıklar kaçınılmazdır. Bu tür atıkların geri kazanımı, bertaraf yöntemleri, tekrar kullanım alanları ve yönetimi gibi konularda yapılacak tüm çalışmalarda her şeyden önce atığın tüm özellikleri dikkate alınmalıdır.

Kömür külü toksik maddeler içermekte ve bu özelliğinden dolayı da çevre ve insan sağlığını tehdit etmektedir. Bu tür atıkların özellikle su ile teması sonucunda hem sağlık hem de çevre kirliliği konusundaki endişeler daha da arttırmaktadır. Kömür külü depolama alanlarında suyun sızarak ve ya akışa geçerek yeraltı ve yerüstü su kaynaklarını kirletme potansiyeli olduğu gibi kuru olarak havaya karışıp canlılara zarar verme potansiyeli vardır. Kömür külü bertaraf yöntemlerinden bir tanesi ve en yaygın olarak kullanılan su ile taşıma ve depolama yöntemi külün bileşimindeki özellikle toksik metallerin suya geçerek çevre bileşenlerinde yayılması ve kül depolama barajlarının patlaması riskinden dolayı Dünyada terk edilmeye başlanmıştır. Geçmişte kül depolama alanları gibi atık barajlarının patlaması ile Dünyada ve ülkemizde çok trajik olaylar meydana gelmiştir. $\mathrm{Bu}$ nedenle bu tür atıkların hem doğal çevrenin korunması hem de çevre sağlığı üzerindeki olumsuz etkilerinin ortadan kaldırılması için uygun şekillerde bertaraf edilmesi veya tekrar kullanımına olanak sağlanması gerekmektedir. Endüstriyel atık olarak geri kazanılmaya elverişli bir malzeme olan kömür küllerinin ve özelliklede uçucu küllerin değişik sektörlerde değerlendirilme olanakları vardır. Bu çalışma kapsamında değerlendirilen birçok çalışmada başta inşaat sektörü olmak üzere farklı sektörlerde de bu atıkların değerlendirilebileceği görülmüştür.

Ülkemizde ise özellikle inşaat sektörü ile ilgili uygulamalarda uçucu kül kullanımının söz konusu olduğu ancak bu uygulamaların tam olarak yaygınlaşmadığı görülmüştür. Bu tür uygulamalarla ilgili yapılacak çalışmalar hem çevre sağlığı hem de ekonomik anlamda topluma katkı sağlayacaktır. Ayrıca sıfır atık yaklaşımı ile söz konusu atıkların tekrardan değerlendirilebiliyor olması da çevre kirliliği uygulamaları konusunda oldukça önemlidir. Bu konu da yapılacak çalışmalar ve yeni kullanım alanlarının belirlenmesi ülkemizde kapladığı alan bakımından sorunlara neden olan bu atıklar için önemli çözüm önerilerinin geliştirilmesini sağlayacaktır.

Sonuç olarak Dünyada çevre mevzuatı gelişmiş ülkelerde olduğu gibi mevcut kül depolama barajları gibi atık barajlarının sızdırma ve patlama riskleri gözden geçirilmeli riskli görülenlerin işletimi durdurularak rehabilite edilmelidir. Yeni kül depolama alanlarının daha az yer kaplaması, çevre sağlı̆̆ı ve hammadde tasarrufu açısından için atık küllerin yeniden kullanımı alternatifleri değerlendirilmeli ve teşvik edilerek bir an önce sulu kül taşıma ve depolama yönteminden taşıdığı riskler dolayı vazgeçilmelidir. 


\section{KAYNAKLAR}

[1] International Energy Agency, "World Energy Outlook Special Report 2016: Energy and Air Pollution," September $11,2016$.

[2] G. Akar, "Kömür Külü Atık Sahalarında Oluşacak Ağır Metal Kirlenmesinin Belirlenmesi”, Yüksek Lisans Tezi, Dokuz Eylül Üniversitesi Fen Bilimleri Enstitüsü, İzmir, 2001.

[3] Environmental Protection Agency, "Hazardous and solid waste management system; Disposal of coal combustion residuals from electric utilities," Federal Register, vol. 83, no.51, 2018.

[4] American Coal Ash Association, "Coal combustion product (CCP) \& use survey report," September 11, 2016.

[5] International Energy Agency, "World Energy Outlook," Paris, France, 2011.

[6] X. Zhang, "Management of coal combustion wastes", IEA Clean Coal Centre, January 2014.

[7] F. Tütünlü and Ü. Atalay, "Utilization of Fly Ash in Manufacturing of Building Bricks", International Ash Utilization Symposium, Center for Applied Energy Research, University of Kentucky, USA, 2001.

[8] U.S. Environmental Protection Agency, Office of Solid Waste and Emergency Response, "Human and Ecological Risk Assessment of Coal Combustion Wastes", pp. 2-4, April, 2010.

[9] L.K.A. Sear, Properties and use of coal fly as: A valuable industrial by-product. Thomas Telford Publishing, 2001.

[10] Y. H. Aruntaş, "Uçucu Küllerin İnşaat Sektöründe Kullanım Potansiyeli," Gazi Üniversitesi Mühendislik Mimarlık Fakültesi Dergisi, vol. 21, no. 1 pp.193-203, 2006.

[11] Sierra Club National, "Protecting our community from toxic coal ash," [Online]. Available: https://content.sierraclub.org. [Accessed: Feb. 11, 2019].

[12] Environmental Health Perspectives, "Balancing Act. Creating the Right Regulation for Coal Combustion Waste," vol. 117, no.1, 2009.

[13] Electric Power Research Institute, "Coal Ash: Characteristics, Management and Environmental Issues,” EPRI Rep., September, 2009.

[14] Environmental Protection Agency, "Report to Congress: Wastes from The Combustion Of Coal By Electric Utility Power Plants," Report no. EPA/530-SW-88-002, 1988.

[15] L. Luther, "Managing Coal Combustion Waste (CCW): Issues with Disposal and Use", Congressional Research Service, January, 2010.

[16] M. Flues, I.M. Sato, M.A. Scapin, M.E.B. Cotrim and I.M.C. Camargo, "Toxic elements mobility in coal and ashes of Figueira coal power plant, Brazil," Fuel, vol. 103, pp. 430-436, 2013.

[17] K.B. Jones, L.F. Ruppert and S. M. Swanson, "Leaching of elements from bottom ash, economizer fly ash, and fly ash from two coal-fired power plants," International Journal of Coal Geology, vol. 94, pp. 337-348, 2012.

[18] R.F. Keefer, Trace element in coal and coal combustion residues. Lewis Publishers, CRC Press, FL, USA, 1993.

[19] D. Alkaya, "Uçucu Küllerin Zemin iyileştirmesinde Kullanılmasının İncelenmesi”, Yapı Teknolojileri Elektronik Dergisi, vol. 5, no. 1, pp. 61-72, 2009.

[20] G. Kaplan, A.B. Gültekin, "Yapı Sektöründe Uçucu Kül Kullanımının Çevresel Ve Toplumsal Etkiler Açısından İncelenmesi," International Sustainable Buildings Symposium, Ankara, Türkiye, 2010.

[21] P. Brown, T. Jones and K. Bérubé, "The internal microstructure and fibrous mineralogy of fly ash from coal-burning power stations," Environmental Pollution, vol. 159, pp. 3324-3333, 2011.

[22] M. Flues, V. Moraes and B.P. Mazzilli, "The influence of a coal fired power plant operation on radionuclide concentrations in soil," Journal of Environmental Radioactivity, vol. 63, pp. 285-294, 2002.

[23] U.S. Environmental Protection Agency. "Appendix Q. 1948-2008 US Historical Damage Cases Associated with Electric Utility Plant CCR Disposal Units," 2009.

[24] S. Mueller, J.W. Mallard, Q. Mao and S.L. Shaw, "Fugitive particulate emission factors for dry fly ash disposal," Journal of the Air \& Waste Management Association, vol. 63, pp. 806-818, 2013.

[25] U.S. Environmental Protection Agency, "Hazardous and solid waste management system; Identification and listing of special wastes; Disposal of coal combustion residuals from electric utilities," pp. 35128-35264, 2010.

[26] B. Breen, "Testimony delivered to Committee on Transportation and Infrastructure, Subcommittee on Water Resources and the Environment," U.S. House of Representatives, Office of Solid Waste and Emergency Response, April 30, 2009.

[27] U.S. Environmental Protection Agency, Office of Solid Waste, "Human and Ecological Risk Assessment of Coal Combustion Wastes," August, 2007.

[28] U.S. Environmental Protection Agency, Office of Solid Waste, "Coal Combustion Waste Damage Case Assessments," 2007.

[29] C. Ferreira, A. Ribeiro and L. Ottosen, "Possible Applications for Municipal Solid Waste Fly Ash," Journal of Hazardous Materials, vol. 96, no. 2-3, pp. 201-216, 2003. 
[30] J. Yang, J. Huang, Y. Su, X. He, H. Tan, W. Yang and B. Strnadel, "Eco-friendly treatment of low-calcium coal fly ash for high pozzolanic reactivity: A step towards waste utilization in sustainable building material," Journal of Cleaner Production, vol. 238, pp. 117962, 2019.

[31] S. Kızgut, D. Çuhadaroğlu, K. Çolak, "Termik Santralı Uçucu Küllerinden Tuğla Üretim Olanaklarının Araştırılması", Türkiye 17. Uluslararası Madencilik Kongresi ve Sergisi-TUMAKS, Zonguldak, 2001, pp. 81-85.

[32] M. Singh and R. Siddique, "Properties of concrete containing high volumes of coal bottom ash as fine aggregate," Journal of Cleaner Production, vol. 91, pp. 269-278, 2015.

[33] İ. Demir, "Uçucu Külün Hafif Yapı Malzemesi Üretiminde Kullanılması,” Yapı Teknolojileri Elektronik Dergisi, vol. 1 , pp. 21-24, 2005.

[34] K. Yin, A. Ahamed and G. Lisak, "Environmental perspectives of recycling various combustion ashes in cement production - A review," Waste Management, vol. 78, pp. 401-416, 2018.

[35] B. Sarı, B. Bayat, "Evsel atık suların fiziko kimyasal arıtımında uçucu külün koagülant olarak kullanımı", Turkish J. Eng. Env. Sci., vol. 26, pp. 65-74. 2002.

[36] H. Binici, R. Gemci, A. Küçükönder, H. H. Solak, "Pamuk Atığı, Uçucu Kül ve Barit İle Üretilen Sunta Panellerin Is1, Ses ve Radyasyon Geçirgenliği Özellikleri," Yapı Teknolojileri Elektronik Dergisi vol. 8, no.1, pp. 16-25, 2012.

[37] G. Güler, E. Güler, Ü. İpekoğlu, H. Mordoğan, "Uçucu Küllerin Özellikleri ve Kullanım Alanları,” Türkiye 19. Uluslararası Madencilik Kongresi ve Fuarı, IMCET, İzmir, 2005, pp. 419-423.

[38] A.C. Pope and D.W. Dockery, "Acute health effects of PM10 pollution on symptomatic and asymptomatic children," American Review of Respiratory Disease, vol.145, no.5, pp. 1123- 1128, 1992.

[39] P.J. Landrigan, C.A. Kimmel, A. Correa and B. Eskenazi, "Children's health and the environment: public health issues and challenges for risk assessment," Environ Health Perspect, vol. 112, no. 2, pp. 257-265, 2003.

[40] C.G. Sears and K. M. Zierold, "Health of Children Living Near Coal Ash," Global Pediatric Health, vol. 4, pp. 1-8, 2017.

[41] S.A. Smith, Testimony of Stephan A. Smith, DVM, Executive Director, Southern Alliance for Clean Energy, Submitted to the U.S. Senate Committee on Environment and Public Works, January 8, 2009.

[42] L. Ruhl, A. Vengosh, G.S. Dwyer, H. Hsu-Kim, A. Deonarine, M. Bergin and J. Kravchenko, "Survey of the potential environmental and health impacts in the immediate aftermath of the coal ash spill in Kingston Tennessee," Environmental Sci. Technology, vol. 43, pp.6329-6333, 2009. 